\title{
Climate zone influences the effect of temperature on the day of artificial insemination on fertility in two Iberian sheep breeds
}

Jose Alfonso Abecia - Jara Máñez •

Angel Macias • Adolfo Laviña - Carlos Palacios

JA Abecia (Corresponding autor) • J Máñez

Instituto Universitario de Investigación en Ciencia Ambientales de Aragón (IUCA). Universidad de Zaragoza, Miguel Servet, 177, 50013 Zaragoza, Spain.

e-mail: alf@unizar.es

\section{A Macias - A Laviña}

Asociación Nacional de Ganaderos de la Raza Rasa Aragonesa (ANGRA), Cabañera Real, s/n, 50800 Zuera, Zaragoza, Spain.

\section{Palacios}

Departamento de Construcción y Agronomía. Facultad de Ciencias Agrarias y Ambientales. Universidad de Salamanca, Spain.

Received: April 24, 2017 • Revised: June 15, 2017 • Accepted: June 21, 2017

\begin{abstract}
The aim of this study was to determine the effect of temperature on the day of artificial insemination (AI) on fertility, and to study how climate zone of the farm may modify this effect, in two breeds of sheep that are reared on the Iberian Peninsula on four farms located within one of three climate zones, based on the Köppen Climate Classification. A total number of 1,931 AI were studied from Spanish farms of the Rasa Aragonesa (RA) (July) and Churra (CH) (June) breeds. Farms were categorized as Köppen BSk (Farm BSk$\mathrm{RA}$; n=229), and Köppen $C f b(\mathrm{Cfb}-\mathrm{RA}$; n=372), Köppen $C s b$ (Csb-CH; n=908), and Köppen $\mathrm{Cfb}(\mathrm{Cfb}-\mathrm{CH} ; \mathrm{n}=422)$. Mean, maximum, and minimum temperatures $\left({ }^{\circ} \mathrm{C}\right)$ were recorded, and thermal amplitude (maximum-minimum temperatures) calculated. Each set of temperature data was distributed between percentile-groups ( $\leq 50 \%$ and $>50 \%$ ), below or above the median. Temperatures at AI were higher $(\mathrm{P}<0.05)$ among successful inseminations than failed inseminations at the two $C f b$ farms. At the other two farms, temperatures on the day of AI were lower $(\mathrm{P}<0.05)$ among ewes that became pregnant than those that did not. At the two $C f b$ farms, fertility rates of the $\leq 50$ and $>50$ percentile groups indicated that inseminations performed when temperatures were within the $>50$ percentile had a higher proportion $(\mathrm{P}<0.05)$ of ewes that became pregnant than did those in the $\leq 50$ group. At the $C f b$ farms Odds Ratio OR were statistically significant and $>1$ for one or more of the meteorological variables under study; meanwhile, in the other two climates, OR were $<1(\mathrm{P}>0.05)$. In conclusion, the effects of temperature on fertility after AI differed depending on the climate zone in which the flocks were reared. The results have implications for the scheduling of insemination dates to achieve the maximal performances.
\end{abstract}

Keywords: climate, fertility, insemination, Köppen, sheep, weather

\section{Introduction}

Artificial insemination (AI) is the oldest technique used in assisted reproduction, and is the technology that has done the most to improve the genetic quality of small ruminants (for review, see Faigl et al 2012). Although it was used in animal reproduction initially for sanitary reasons, it has become the method of choice for the rapid introduction of specific genes into a population as a mean of improving production traits. In small-ruminant breeding programs, AI has allowed the genetic evaluation of rams and bucks, the diffusion of genetic improvement, and has helped to control lambing by manipulating birth dates to meet market demands. Numerous factors can affect ovine and caprine AI success; e.g., farm, year, season, AI technique, technician (dairy sheep, Anel et al 2005); number of previous parturitions of the ewe, lambing-AI interval, month of AI, technician, farm, and inseminating ram (meat sheep, Palacín et al 2012), or nutrition, breeding season, environmental conditions, parity, breed, farm, depth of semen deposition, and extender composition (goats, Mellado et al 2006; Salvador et al 2005; Nunes and Salgueiro 2011; Arrébola et al 2015).

In addition, non-management factors such as weather can affect fertility after AI. Our research has identified relationships between weather and fertility after AI in sheep and goats in Spain. Low temperature and solar radiation, and high relative humidity and rainfall were detrimental to fertility rate after AI in Murciano Granadina goats (Arrébola et al 2015). In Churra sheep, depending on season, temperature can be a protective or a risk factor for fertility (Palacios and Abecia 2015). In our study of spring AI, low temperatures and high rainfall were detrimental to fertility rate after AI in Payoya goats, and low temperatures and low rainfall were detrimental to fertility rate in Rasa Aragonesa sheep (Abecia 
et al 2016). In the Florida goat, mean temperature was beneficial, and minimum temperature was detrimental to fertility rate after AI (Arrébola et al 2016). Exposure to elevated ambient temperatures has negative effects on the biological functions of sheep, which is reflected in diminished production and reproduction traits (for review, see Marai et al 2007). Unlike the technical aspects that are essential to the success of AI, weather cannot be controlled; however, scheduling AI dates based on weather forecasts might increase fertility rates in small ruminants.

Climate and weather vary geographically, and breed and particularly location of the farm might influence their effects on fertility. Climate and location are the factors that have the most significant effect on livestock production (for review, see Lamy et al 2012). The Köppen Climate Classification System assumes that animal production is a vital economic activity in all but polar climates, although other climates differ in the constraints they impose on animal production, e.g., extreme temperatures or prolonged wet or dry periods. Lamy et al (2012) argued that farm animals have been artificially selected under climate conditions to develop ways in which to cope with factors associated with climate variability, either by maintaining body temperature (homeothermia) under high or low environmental temperatures, or by adapting to seasonal nutrition scarcity (Lamy et al 2012).

The aim of this study was to determine the effect of temperature on the day of AI on fertility, and to study how climate zone of the farm may modify this effect, in two breeds of sheep that are reared on the Iberian Peninsula on four farms located within one of three climate zones, based on the Köppen Climate Classification.

\section{Materials and Methods}

Animals and AI procedures

In total, 1,931 AIs were performed on four sheep farms in Aragón (Rasa Aragonesa breed, RA) in July and Castilla y León (Churra breed, CH), Spain, in June. Farms of the same breed followed the same standardized procedures, especially the nutrition, and milking systems for the $\mathrm{CH}$ breed. RA is a native Spanish breed that is bred for meat production and is well adapted for intensive and extensive production systems ( 500,000 heads). $\mathrm{CH}$ is a Spanish sheep breed reared in Castilla y Leon (Northern Spain), which is bred for milk and meat production $(\sim 150,000$ heads).

Estrus was synchronized and ewes were inseminated on the farm following procedures approved by the 'Sheep Health Management Guide' of the Ministry of Agriculture, Food and Environment of the Spanish Government (see Palacios and Abecia 2015). To synchronize estrus, intravaginal fluorogestone acetate sponges (Chronogest, MSD
Animal Health, Madrid, Spain) were administered for $14 \mathrm{~d}$, and 428 (Churra) or 480 (Rasa Aragonesa) IU eCG were administered at pessary withdrawal (Folligon, MSD Animal Health). Ewes were cervical-inseminated with fresh semen 56 $\pm 1 \mathrm{~h}$ after sponge removal. Semen was obtained from Rasa Aragonesa and Churra rams of proven fertility, which were housed individually at the CERSYRA Centre of the Aragon Government (Movera, Zaragoza, Spain; $41^{\circ} \mathrm{N} 0^{\circ} \mathrm{W}$ ), and OVIGEN (Toro, Zamora, Spain; $41^{\circ} \mathrm{N} 5^{\circ} \mathrm{W}$ ), respectively. Semen was kept refrigerated $\left(15^{\circ} \mathrm{C}\right)$ until AI. To determine whether ewes became pregnant, ultrasonography was performed 40 days after AI.

Farm locations and climates

The farms on which AI was performed were categorized based on their location and the Köppen Climate Classification of the Iberian Peninsula (Iberian Climate Atlas, State Meteorological Agency of Spain, 2011) (Figure 1). For the RA breed, the farms were in Huermeda, Zaragoza

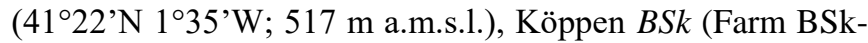
RA) ( $\mathrm{n}=229$ AIs), and Santa Cilia de Jaca, Huesca (42 $33^{\circ} \mathrm{N}$ 042’W; 649 m a.m.s.1.), Köppen $C f b$ (Farm Cfb-RA) (n=372 AIs). For the $\mathrm{CH}$ breed, farms were in Castromonte, Valladolid (41 ${ }^{\circ} 46^{\prime} \mathrm{N} 5^{\circ} 2^{\prime} \mathrm{W} ; 840 \mathrm{~m}$ a.m.s.l.), Köppen $C s b$ (Farm Csb-CH) (n=908 AIs), and Fresnillo de las Dueñas, Burgos (41 ${ }^{\circ} 38^{\prime} \mathrm{N} 3^{\circ} 38^{\prime} \mathrm{W}$; 805 m a.m.s.1.), Köppen Cfb (Farm $\mathrm{Cfb}-\mathrm{CH})(\mathrm{n}=422$ AIs). Historical monthly mean, maximum, and minimum temperatures of the four locations are presented in Figure 2 and 3.
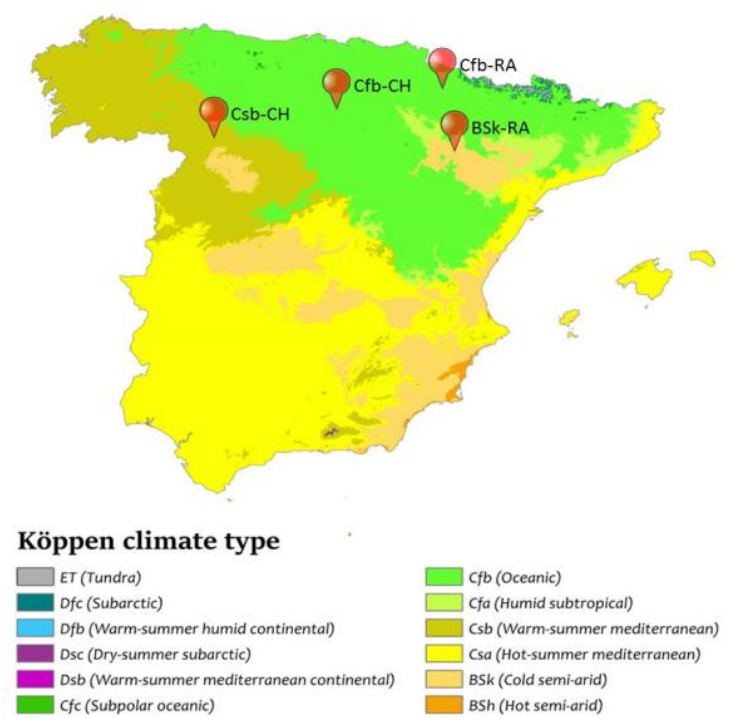

Figure 1 Köppen Climate Types in Spain and the location of the four farms in the study. The isotherm used to distinguish between temperate (C) and continental (D) climates was $-3^{\circ} \mathrm{C}$. Data source: Climate types calculated from data from WorldClim.org (Author Adam Peterson, Wikipedia Commons). RA: Rasa Aragonesa breed; $\mathrm{CH}$ : Churra breed. 
The three climates encompassed by the farms are the most important in the Iberian Peninsula. The BSk climate is defined as "cold semi-arid", with $k$ denoting that at least one month's average daily temperature is below $0{ }^{\circ} \mathrm{C}$, and little precipitation. In Spain, that climate is widespread in the southeast and in the Ebro Valley and less common in the southern central plateau, Extremadura, and the Balearic Islands. The $C f b$ climate is defined as "temperate oceanic climate", with a dry season and temperate summer; the coldest monthly average is $>0{ }^{\circ} \mathrm{C}$, all months have average monthly temperatures $<22{ }^{\circ} \mathrm{C}$, at least four months that have an average $10{ }^{\circ} \mathrm{C}$, and there is no significant seasonally in precipitation. In Spain, that climate occurs in the Cantabrian Mountains, in the Iberian mountain ranges, part of the northern central plateau region, and a large portion of the Pyrenees. The $C s b$ climate is defined as "warm-summer Mediterranean climate", temperate with dry or temperate summer; the coldest month has an average above $0{ }^{\circ} \mathrm{C}$, all months have average daily temperatures below $22^{\circ} \mathrm{C}$, at least four months have averages above $10{ }^{\circ} \mathrm{C}$, there is at least three times as much precipitation in the wettest month of winter as there is in the driest month of summer, and the driest month of summer receives $<30 \mathrm{~mm}$. That climate covers most of the northeast of the Peninsula, almost all of the west coast of Mainland Portugal, and numerous mountainous regions within the Peninsula.

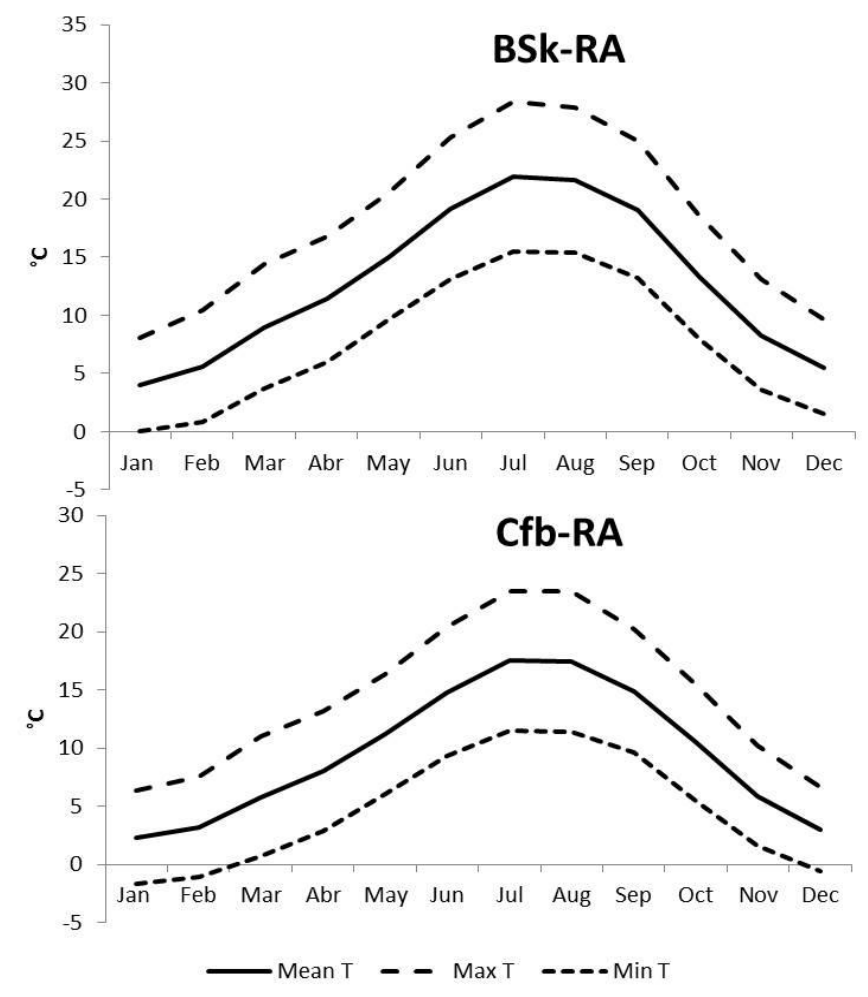

Figure 2 Monthly mean, maximum, and minimum ambient temperatures $\left({ }^{\circ} \mathrm{C}\right)$ at two Rasa Aragonesa (RA) farms which were classified as BSk (Huermeda) or $C f b$ (Santa Cilia de Jaca).
Meteorological data

Mean, maximum, and minimum ambient temperatures $\left({ }^{\circ} \mathrm{C}\right)$ were recorded at the local meteorological station of each location, and thermal amplitude (difference between maximum and minimum temperatures) was calculated.

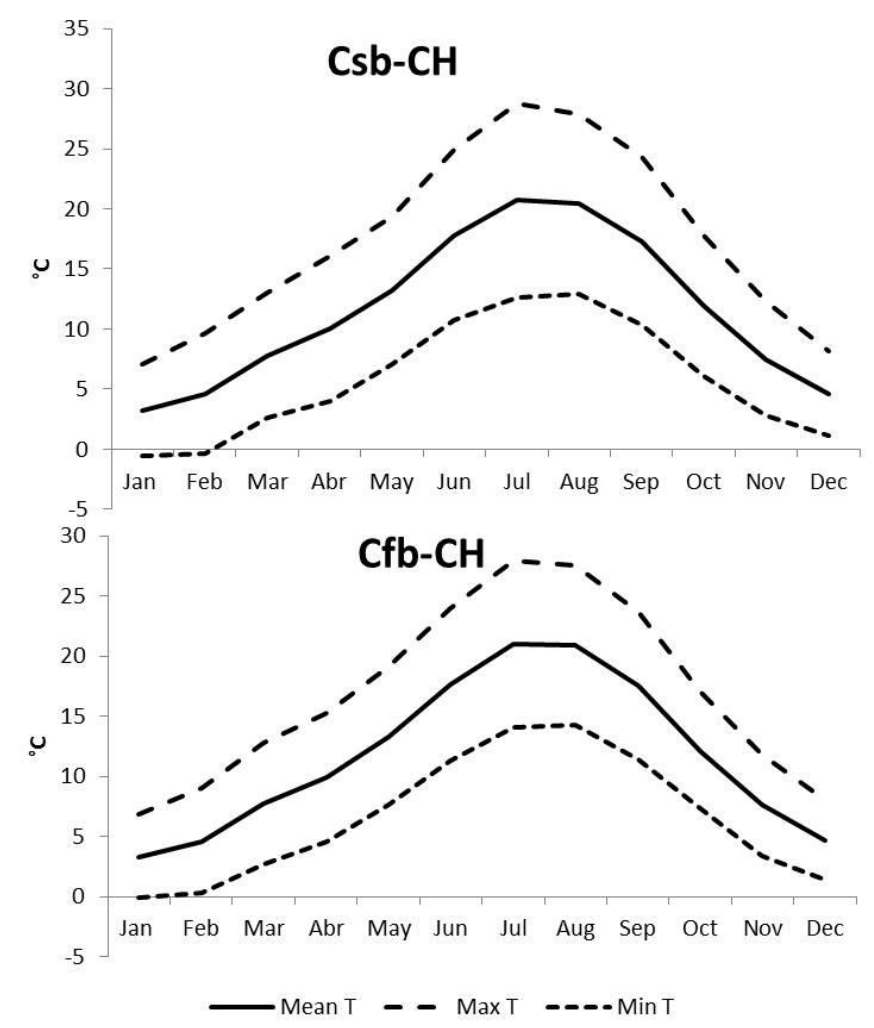

Figure 3 Monthly mean, maximum, and minimum ambient temperatures $\left({ }^{\circ} \mathrm{C}\right)$ at two Churra $(\mathrm{CH})$ farms under study, which were classified as $C s b$ (Castromonte) or $C f b$ (Fresnillo).

Statistical analysis

For each farm, differences in fertility rates between years were assessed by Chi-square tests. The data were analyzed as a case-control study (case = not pregnant after AI; control = pregnant after $\mathrm{AI}$ ). To assess significant differences in the temperature of successful and failed inseminations, an ANOVA test was performed with being or not pregnant as the factor under study. Thereafter, temperatures were converted to categorical variables (dummy variables), with the median value of each continuous meteorological variable as the cutoff point ( 0 , below median; 1 , above median); hence, each set of temperature data was distributed between percentile-groups ( $\leq 50 \%$ and $>50 \%$ ). To divide the sets of data into two percentile-groups based in their median values, we used 'visual binning' (SPSS), which allows for interactive choice in creating a categorical variable from a quantitative variable. Differences in the fertility rates of the two temperature 
percentile-groups were evaluated by Chi-square and MantelHaenszel Chi-square tests. Results are presented with the Odds Ratio (OR) and the 95\% Confidence Interval (CI) by farm. The OR can indicate whether an exposure (temperature) is a risk factor for a particular outcome (pregnancy or not) and can be used to compare the magnitudes of various risk factors for the outcome (Szumilas 2010). An $\mathrm{OR}=1$ indicates that the exposure does not affect the odds of outcome, an OR $>1$ that the exposure is associated with higher than even odds of outcome (protective factor), and an $\mathrm{OR}<1$ that the exposure is associated with lower than even odds of outcome (risk factor). Statistical analyses were performed using SPSS 22.0 (Chicago, IL, USA).

\section{Results}

Mean fertility rates at the BSk-RA, Cfb-RA, Csb-CH, and $\mathrm{Cfb}-\mathrm{CH}$ farms were $68,61,53$, and $49 \%$, respectively (Figure 3 and 4). Mean, maximum, and minimum temperatures on the day of AI were significantly $(\mathrm{P}<0.05)$ higher among successful inseminations than they were among failed inseminations at the two $C f b$ farms (Tables 1 and 2). At the BSk-RA and the $\mathrm{Csb}-\mathrm{CH}$ farms, however, the temperatures on the day of $\mathrm{AI}$ were significantly $(\mathrm{P}<0.05)$ lower among ewes that became pregnant than they were among those that did not (Tables 1 and 2). At the BSk-Ra and $\mathrm{Cfb}-\mathrm{CH}$ farms, thermal amplitude was significantly lower among ewes that became pregnant than it was among those that did not; at the other two farms, however, the opposite was true $(\mathrm{P}<0.05)$.

At the two $C f b$ farms, the fertility rates of the $\leq 50$ and $>50$ percentile groups based on the three temperature variables indicated that inseminations that were performed when temperatures were within the $>50$ percentile had a significantly $(\mathrm{P}<0.05)$ higher proportion of ewes that became pregnant than did those in the $\leq 50$ group. In contrast, at the BSk-RA and the Csb-CH farms, fertility rate was significantly higher among the ewes in the $\leq 50$ percentile group than it was among ewes in the $>50$ percentile group $(\mathrm{P}<0.05)$ (Tables 3 and 4).

Table 1 Meteorological conditions (mean \pm SEM) at the time of July artificial inseminations and pregnancy success (Yes or No) of Rasa Aragonesa (RA) ewes at two farms in Spain, which were classified as $B S k$ or $C f b$ in the Köppen Climate Classification.

\begin{tabular}{lcccc}
\hline Köppen Climate Classification & \multicolumn{2}{c}{ Farm BSk-RA } & \multicolumn{2}{c}{ Farm Cfb-RA } \\
\hline Pregnancy & No & Yes & No & Yes \\
\hline $\mathrm{n}$ & 80 & 149 & 144 & 228 \\
\hline Mean Temperature $\left({ }^{\circ} \mathrm{C}\right)$ & $24.84 \pm 0.22^{\mathrm{a}}$ & $24.14 \pm 0.21^{\mathrm{b}}$ & $22.21 \pm 0.19^{\mathrm{e}}$ & $23.05 \pm 0.16^{\mathrm{f}}$ \\
Maximum Temperature $\left({ }^{\circ} \mathrm{C}\right)$ & $33.56 \pm 0.35^{\mathrm{a}}$ & $32.55 \pm 0.28^{\mathrm{b}}$ & $30.81 \pm 0.19^{\mathrm{a}}$ & $31.27 \pm 0.14^{\mathrm{b}}$ \\
Minimum Temperature $\left({ }^{\circ} \mathrm{C}\right)$ & $15.93 \pm 0.21^{\mathrm{a}}$ & $15.10 \pm 0.23^{\mathrm{b}}$ & $13.17 \pm 0.27^{\mathrm{e}}$ & $14.56 \pm 0.24^{\mathrm{f}}$ \\
Thermal Amplitude $\left({ }^{\circ} \mathrm{C}\right)$ & $17.63 \pm 0.30^{\mathrm{e}}$ & $17.44 \pm 0.21^{\mathrm{f}}$ & $17.63 \pm 0.29^{\mathrm{a}}$ & $16.71 \pm 0.25^{\mathrm{b}}$
\end{tabular}

In the same farm: a,b p<0.05; c,d $\mathrm{P}<0.01 ; \mathrm{e}, \mathrm{f} \mathrm{P}<0.001$

At the Cfb-RA and the $\mathrm{Cfb}-\mathrm{CH}$ farms, the OR were statistically significant for one or more of the meteorological variables under study (Table 5). On those farms, the OR for mean, maximum, and minimum temperatures were $>1$, and the OR for thermal amplitude was $<1$. In the other two farms, the OR were $<1$, but were not statistically significant.

\section{Discussion}

The results of our study suggest that, in the $C f b$ climate in the Iberian Peninsula, high ambient temperature is a protective factor in the summer meteorological season AI (June and July) of both breeds, such that ewes are more likely to become pregnant if the temperature is higher, rather than lower. The opposite was true for the ewes on the farms in the other two climates. At the farms in the BSk and $C s b$ climates, high temperatures in June and July appeared to be risk factors for fertility after AI in both breeds. Few studies have investigated the role of climate zone efficiency in the success of any type of assisted reproduction, especially in sheep. In a study of efficiency of embryo transfer in cattle in China, Feng et al (2014) observed that, in mid-temperate areas, summer was the most efficient season. In warm zones, autumn was the best and, in sub-tropical zones, fertility rate was highest in winter. They concluded that, to obtain the highest success in embryo transfer, the optimum temperature and humidity could be created artificially in each climate zone, or a seasonal program of embryo transfers could be scheduled for each zone. 
Table 2 Meteorological conditions (mean \pm SEM) at the time of June artificial inseminations and pregnancy success (Yes or No) of Churra (CH) ewes in two farms in Spain, which were classified as $C s b$ or $C f b$ in the Köppen Climate Classification.

\begin{tabular}{lcccc}
\hline Köppen Climate Classification & \multicolumn{2}{c}{ Farm Csb-CH } & \multicolumn{2}{c}{ Farm Cfb-CH } \\
\hline Pregnancy & No & Yes & No & Yes \\
\hline $\mathrm{n}$ & 428 & 480 & 219 & 203 \\
\hline Mean Temperature $\left({ }^{\circ} \mathrm{C}\right)$ & $19.38 \pm 0.22^{\mathrm{e}}$ & $18.90 \pm 0.32^{\mathrm{f}}$ & $20.77 \pm 0.16^{\mathrm{c}}$ & $21.47 \pm 0.17^{\mathrm{d}}$ \\
Maximum Temperature $\left({ }^{\circ} \mathrm{C}\right)$ & $27.53 \pm 0.32^{\mathrm{e}}$ & $26.99 \pm 0.32^{\mathrm{f}}$ & $31.25 \pm 0.18^{\mathrm{e}}$ & $31.64 \pm 0.21^{\mathrm{f}}$ \\
Minimum Temperature $\left({ }^{\circ} \mathrm{C}\right)$ & $11.72 \pm 0.19^{\mathrm{c}}$ & $11.08 \pm 0.18^{\mathrm{d}}$ & $9.30 \pm 0.25^{\mathrm{e}}$ & $10.50 \pm 0.194^{\mathrm{f}}$ \\
Thermal Amplitude $\left({ }^{\circ} \mathrm{C}\right)$ & $15.82 \pm 0.25^{\mathrm{e}}$ & $15.91 \pm 0.25^{\mathrm{f}}$ & $21.95 \pm 0.31^{\mathrm{a}}$ & $21.14 \pm 0.28^{\mathrm{b}}$ \\
\hline
\end{tabular}

In the same farm: a,b $\mathrm{p}<0.05 ; \mathrm{c}, \mathrm{d} \mathrm{P}<0.01 ; \mathrm{e}, \mathrm{f} \mathrm{P}<0.001$

Table 3 Fertility rate $(\%)$ and mean $( \pm$ SEM) of the $\leq 50$ percentile and $>50$ percentile of the meteorological factors at the time of July artificial insemination in Rasa Aragonesa (RA) ewes in two farms in Spain, which were classified as $B S k$ or $C f b$ in the Köppen Climate Classification.

\begin{tabular}{lcccc}
\hline $\begin{array}{l}\text { Köppen Climate } \\
\text { Classification }\end{array}$ & \multicolumn{2}{c}{ Farm BSk-RA } & \multicolumn{2}{c}{ Farm Cfb-RA } \\
\hline & $\begin{array}{c}50 \text { th } \\
\text { percentile }\end{array}$ & $\begin{array}{c}>50^{\text {th }} \\
\text { percentile }\end{array}$ & $\begin{array}{c}\leq 50 \text { th } \\
\text { percentile }\end{array}$ & $\begin{array}{c}>50 \text { th } \\
\text { percentile }\end{array}$ \\
\hline Mean Temperature & $69 \%^{\mathrm{c}}$ & $60 \%^{\mathrm{d}}$ & $58 \%$ & $67 \%$ \\
$\left({ }^{\circ} \mathrm{C}\right)$ & $23.11 \pm 0.19$ & $26.19 \pm 0.13$ & $21.31 \pm 0.15$ & $25.28 \pm 0.11$ \\
\hline Maximum Temperature & $68 \%^{\mathrm{c}}$ & $62 \%^{\mathrm{d}}$ & $59 \%$ & $66 \%$ \\
$\left({ }^{\circ} \mathrm{C}\right)$ & $30.51 \pm 0.17$ & $35.63 \pm 0.23$ & $29.90 \pm 0.15$ & $33.74 \pm 0.73$ \\
\hline Minimum Temperature & $69 \%^{\mathrm{c}}$ & $60 \%^{\mathrm{d}}$ & $54 \%^{\mathrm{e}}$ & $75 \%{ }^{\mathrm{f}}$ \\
$\left({ }^{\circ} \mathrm{C}\right)$ & $14.27 \pm 0.25$ & $16.98 \pm 0.02$ & $11.88 \pm 0.14$ & $17.98 \pm 0.29$ \\
\hline Thermal Amplitude & $67 \%^{\mathrm{c}}$ & $62 \%^{\mathrm{d}}$ & $65 \%^{\mathrm{a}}$ & $57 \%^{\mathrm{b}}$ \\
$\left({ }^{\circ} \mathrm{C}\right)$ & $17.17 \pm 0.17$ & $17.98 \pm 0.33$ & $14.32 \pm 0.20$ & $20.00 \pm 0.20$ \\
\hline
\end{tabular}

In the same farm: a,b p<0.05; c, $\mathrm{d}<<0.01 ; \mathrm{e}, \mathrm{f} \mathrm{P}<0.001$

Table 4 Fertility rate $(\%)$ and mean $( \pm$ SEM) of the $\leq 50$ percentile and $>50$ percentile of the meteorological factors at the time of June artificial insemination in Churra $(\mathrm{CH})$ ewes in two farms in Spain, which were classified as $C s b$ or $C f b$ in the Köppen Climate Classification.

\begin{tabular}{|c|c|c|c|c|}
\hline \multicolumn{5}{|l|}{ Köppen Climate } \\
\hline \multirow[t]{3}{*}{ Classification } & \multicolumn{2}{|c|}{ Farm Csb-CH } & \multicolumn{2}{|c|}{ Farm $\mathrm{Cfb}-\mathrm{CH}$} \\
\hline & $\leq 50$ th & $>50^{\text {th }}$ & $\leq 50$ th & $>50$ th \\
\hline & percentile & percentile & percentile & percentile \\
\hline Mean Temperature & $54 \% \mathrm{e}^{\mathrm{e}}$ & $51 \%{ }^{\mathrm{f}}$ & $43 \%{ }^{\mathrm{c}}$ & $55 \%{ }^{\mathrm{d}}$ \\
\hline$\left({ }^{\circ} \mathrm{C}\right)$ & $15.71 \pm 0.14$ & $23.40 \pm 0.06$ & $19.16 \pm 0.05$ & $23.77 \pm 0.05$ \\
\hline Maximum Temperature & $54 \% \mathrm{e}^{\mathrm{e}}$ & $51 \%^{\mathrm{f}}$ & $43 \%^{c}$ & $56 \%{ }^{d}$ \\
\hline$\left({ }^{\circ} \mathrm{C}\right)$ & $22.21 \pm 0.23$ & $33.54 \pm 0.05$ & $29.43 \pm 0.09$ & $34.20 \pm 0.13$ \\
\hline Minimum Temperature & $54 \% \mathrm{e}^{\mathrm{e}}$ & $51 \%{ }^{\mathrm{f}}$ & $46 \%{ }^{\mathrm{e}}$ & $51 \%{ }^{\mathrm{f}}$ \\
\hline$\left({ }^{\circ} \mathrm{C}\right)$ & $8.67 \pm 0.13$ & $14.61 \pm 0.10$ & $7.98 \pm 0.23$ & $12.17 \pm 0.02$ \\
\hline Thermal Amplitude & $52 \% \mathrm{e}^{\mathrm{e}}$ & $54 \%{ }^{\mathrm{f}}$ & $49 \% \mathrm{e}^{\mathrm{e}}$ & $48 \%{ }^{\mathrm{f}}$ \\
\hline$\left({ }^{\circ} \mathrm{C}\right)$ & $10.69 \pm 0.14$ & $20.33 \pm 0.07$ & $17.26 \pm 0.12$ & $24.51 \pm 0.19$ \\
\hline
\end{tabular}

In the same farm: a,b p<0.05; c,d P<0.01; e,f P<0.001 
In our study of two sheep breeds reared in three climates, each situation differed in fertility rate after AI. It appears that each genotype has adapted its physiology to specific climates. The high production by European livestock breeds is merely a result of hundreds of years of artificial selection for a specific purpose; however, the low production by native livestock does not indicate inferiority, rather, it reflects a perfect adaptation to a specific environment (Gomes da Silva 2010). In the fine-woolled Merino sheep reared in Australia, the strains that had been selected by breeders to perform best in its native environment would be expected to have relative performances that would differ among some environments (Dolling 1975). In that study, the original ewes of each strain were dispersed at random into three areas; after which, their wool quality was measured.
The Fine strain performed better at one location (Armidale) than was expected based on its relative performance elsewhere. None of the other strains had any special adaptations for any of the environments. In another study, Dun et al (1966) found a significant interaction effect of strain $\mathrm{x}$ season of mating for each of three measures of reproductive performance. In our study, the RA and the $\mathrm{CH}$ breeds differed in their response to temperature, which was influenced by the climate zone in which they had been reared, therefore, probably, farmers of these breeds have for years applied some form of genetic selection. A species or breed can adapt genetically to the environment in which it has been reared for a considerable period (Dolling 1975). Breeders can use artificial selection to influence that adaptive process in domestic livestock.

Table 5 Odds ratios of mean, maximum, and minimum temperatures, and thermal amplitude (maximum - minimum temperatures) on the day of artificial insemination in Rasa Aragonesa (RA) and Churra (CH) ewes at two farms in Spain, which were classified as $B S k, C s b$, or $C f b$ in the Köppen Climate Classification.

\begin{tabular}{lcccc}
\hline Farm & Independent variables & Odds ratio & $95 \%$ confidence interval & $\mathrm{P}$ \\
\hline BSk-RA & Mean temperature & 0.685 & $0.395-1.186$ & 0.177 \\
& Maximum temperature & 0.756 & $0.439-1.304$ & 0.315 \\
& Minimum temperature & 0.685 & $0.395-1.186$ & 0.177 \\
& Thermal amplitude & 0.795 & $0.461-1.371$ & 0.409 \\
\hline Cfb-RA & Mean temperature & 1.455 & $0.934-2.267$ & 0.097 \\
& Maximum temperature & 1.373 & $0.868-2.172$ & 0.176 \\
& Minimum temperature & 2.536 & $1.587-4.052$ & 0.0001 \\
& Thermal amplitude & 0.451 & $0.295-0.691$ & 0.0001 \\
\hline Csb-CH & Mean temperature & 0.873 & $0.672-1.135$ & 0.311 \\
& Maximum temperature & 0.873 & $0.672-1.135$ & 0.134 \\
& Minimum temperature & 0.877 & $0.675-1.139$ & 0.325 \\
& Thermal amplitude & 1.074 & $0.827-1.395$ & 0.591 \\
\hline $\mathrm{Cfb}-\mathrm{CH}$ & Mean temperature & 1.687 & $1.143-2.491$ & 0.009 \\
& Maximum temperature & 1.687 & $1.143-2.491$ & 0.009 \\
& Minimum temperature & 1.217 & $0.829-1.787$ & 0.316 \\
& Thermal amplitude & 0.952 & $0.645-1.704$ & 0.803 \\
\hline
\end{tabular}

A large study involving 32 old, autochthonous sheep breeds worldwide provided strong evidence for selective signals at 230 single nucleotide polymorphisms (SNPs) that are associated with adaptation to local climates ( $\mathrm{Lv}$ et al 2014). Most (82\%) of the candidate SNPs showed significant correlations between allele frequencies and climatic variables in native populations from a wide range of geographic origins and climates. The implication is that adaptations to local climates have shaped the spatial distribution of specific variants and, therefore, these loci are likely involved in the adaptation to environmental challenges by sheep. In our study, at each farm, annual temperatures on the day of AI varied
(Figure 4 and 5). Probably, inter-annual variation in weather has a significant effect on pasture production, which affects the productivity, the financial and environmental outcomes of livestock farms, and necessitates adaptive management ( $\mathrm{Li}$ et al 2012). In our study, temperature had a similar effect on the fertility of ewes of both breeds in the $C f b$ climate zones, where temperature and fertility were positively correlated, and the OR indicated that temperature was a protective factor in that climate. That zone occurred in mountain areas, where the pasture areas were at $\sim 1000-1200 \mathrm{~m}$ a.m.s.l. The sheep traditionally reared in that location might exhibit local physiological adaptations. For instance, extensively managed 
hill ewes in the UK, which often live in harsh and unfavorable environments, exhibit several physiological traits that differ from those of lowland ewes (Dwyer and Lawrence 2005). Zohary et al (1998) suggested that, largely, unconscious selection has shaped many of the morphological, physiological, and behavioral traits that characterize domestic sheep and goats, which has distinguished them from their wild counterparts.

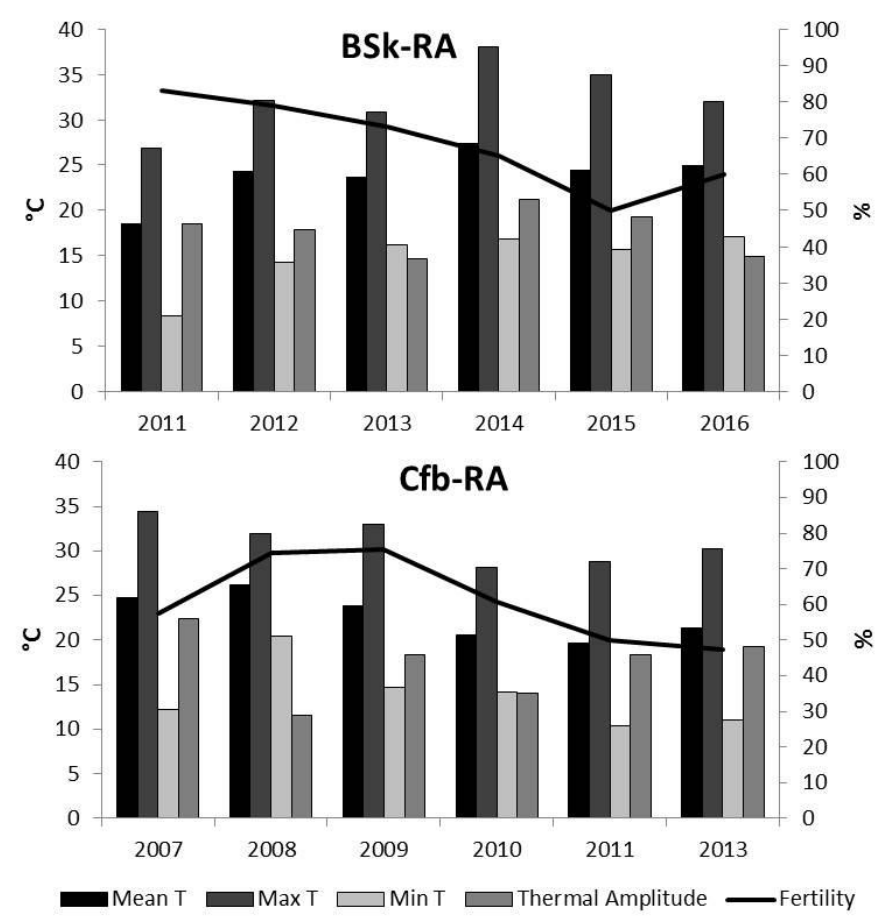

Figure 4 Fertility (\%) and mean, maximum, and minimum temperatures $(\mathrm{T})\left({ }^{\circ} \mathrm{C}\right)$ on the day of July artificial insemination of Rasa Aragonesa (RA) ewes at two farms in Spain, which were classified as $B S k$ or $C f b$ in the Köppen Climate Classification.

\section{Conclusions}

In conclusion, depending on the climate zone in which the flocks were reared, the effects of temperature on the day of AI on fertility differed in two autochthonous Spanish breeds. The results have implications for the strategic decisions taken by the farmer or the veterinary team to alter either the natural or the housing environment to identify the optimal time for AI, and for the scheduling of insemination dates to achieve the maximal performances.

\section{Acknowledgments}

We thank the farmers who participated in this study and Bruce MacWhirter for assisting with the English version of the manuscript.
In earlier studies, we demonstrated that the highest fertility rates could be achieved if temperatures are high for spring and summer AI in the RA (Abecia et al 2016) and the $\mathrm{CH}$ breeds (Palacios and Abecia 2015), respectively. Following our study of the influence of climate, it is clear that, to predict the optimal weather conditions in which to inseminate a particular breed at a specific time of year, the climate zone of the farm is an essential factor to be considered.

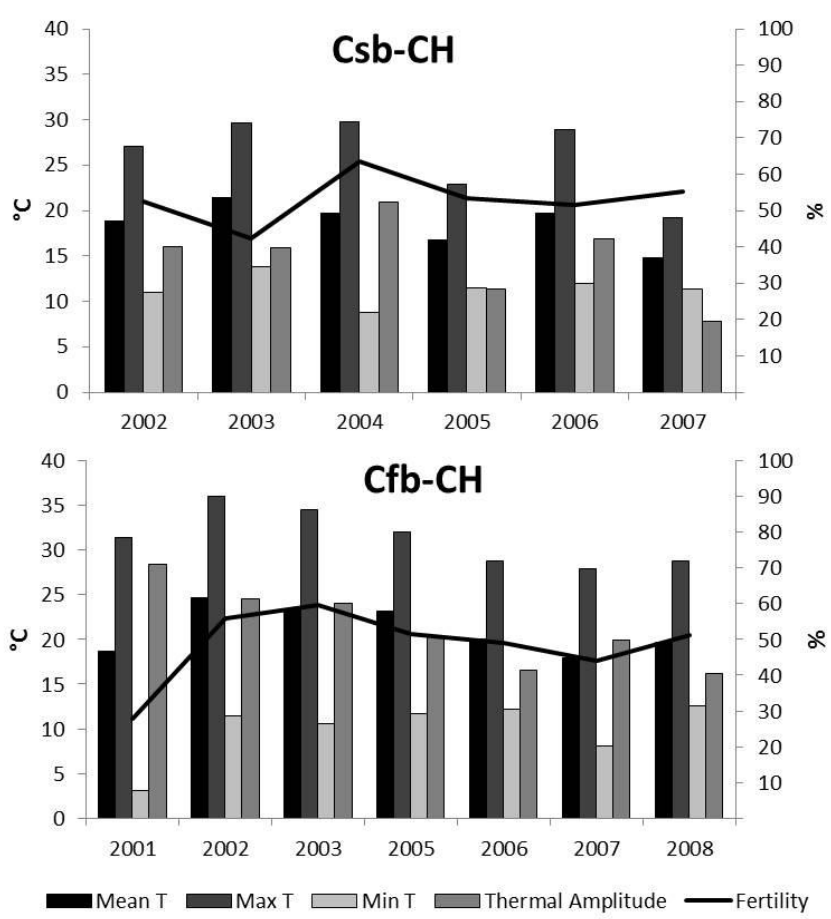

Figure 5 Fertility $(\%)$ and mean $( \pm$ S.E.M.), maximum, and minimum temperatures $(\mathrm{T})\left({ }^{\circ} \mathrm{C}\right)$ on the day of June artificial insemination of Churra $(\mathrm{CH})$ ewes at two farms in Spain, which were classified as $C s b$ or $C f b$ in the Köppen Climate Classification.

\section{References}

Abecia JA, Arrébola F, Macías A, Laviña A, González-Casquet O, Benítez F, Palacios C (2016) Temperature and rainfall are related to fertility rate after spring artificial insemination in small ruminants. International Journal of Biometeorology 60:1603-1609.

Anel L, Kaabi M, Abroug B, Alvarez M, Anel E, Boixo JC, de la Fuente LF, Paz P (2005) Factors influencing the success of vaginal and laparoscopic artificial insemination in Churra ewes: a field assay. Theriogenology 63:1235-1247.

Arrébola F, Sánchez M, López MD, Rodríguez M, Pardo B, Palacios C, Abecia JA. (2016a) Effects of weather and management factors on fertility after artificial insemination in Florida goats: A ten-year study. Small Ruminant Research 137:47-52.

Arrébola F, Palacios C, Gil MJ, Abecia JA (2016b) Management and meteorological factors affect fertility after artificial insemination in 
Murciano-Granadina goats. Animal Production Science 56: 19061912.

Dolling CHS (1975) Sheep and wool production in the different ecological regions in Australia with emphasis on developments in breeding. South African Journal of Animal Science 5:181-187.

Dun RB, Alexander R, Smith MD (1966) An interaction between strain of Merino ewe and season of joining. Proceedings of the Australian Society of Animal Production 6:66.

Dwyer CM, Lawrence AB (2005) A review of the behavioural and physiological adaptations of hill and lowland breeds of sheep that favour lamb survival. Applied Animal Behaviour Science 92:235260.

Faigl V, Vass N, Jávor A, Kulcsár M, Solti L, Amiridis G, Cseh DS (2012) Artificial insemination of small ruminants - a review. Acta Veterinaria Hungarica 60:115-129.

Feng W, Shenyuan W, Dong Z, Lidong H, Lu L, Chunhua H, Gang Z, Jinlong H, Bingping W, Yiyi L, Caiyun L, Jing P, Zhichao Z, Huanmin Z, Li Z (2014) Effects of seasons on embryo transfer of cattle in different climatic zones. Animal Husbandry and Feed Science 6:188-191.

Gomes Da Silva RG (2006) Weather and climate and animal production. Guide to agricultural meteorological practices (GAMP). http://www.agrometeorology.org/files-

folder/repository/gamp_chap_11.pdf. Accessed 26 April 2017.

Iberian Climate Atlas (2011) Agencia Estatal de Meteorología. Ministerio de Medio Ambiente y Medio Rural y Marino de España. Instituto de Meteorologia de Portugal.

Lamy E, van Harten S, Sales-Baptista E, Mendes Guerra MM, Martinho de Almeida A (2012) Factors influencing livestock productivity. In: Sejian V, Naqvi SMK, Ezeji T, Lakritz J, Lal R (eds) Environmental Stress and Amelioration in Livestock Production. Springer Berlin Heidelberg, Germany, pp 19-51.

Li FY, Vibart R, Dynes RA, Vogeler I, Brown M (2012) Effects of weather variability on sheep and beef farming in northern Southland, New Zealand: A modelling analysis. Proceedings of the New Zaland Grassland Association 74:77-84.

Lv FG, Agha S, Kantanen J, Colli L, Stucki S, Kijas JW, Joost S, Li MH, Marsan PA (2014) Adaptations to climate-mediated selective pressures in sheep. Molecular Biology and Evolution 31:3324-3343.

Marai IFM, El-Darawany AA, Fadiel A, Abdel-Hafez MAM (2007) Physiological traits as affected by heat stress in sheep-a review. Small Ruminant Research 71:1-12.

Mellado M, Valdez R, Garcia JE, Lopez R, Rodriguez A (2006) Factors affecting the reproductive performance of goats under intensive conditions in a hot arid environment. Small Ruminant Research 63:110-118.

Nunes JF, Salgueiro CCM (2011) Strategies to improve the reproductive efficiency of goats in Brazil. Small Ruminant Research 98:176-184.

Palacín I, Yániz JL, Fantova E, Blasco ME, Quintín-Casorrán FJ, Sevilla-Mur E, Santolaria P (2012) Factors affecting fertility after cervical insemination with cooled semen in meat sheep. Animal Reproduction Science 132:139-144.

Palacios C, Abecia JA (2015) Meteorological variables affect fertility rate afterintrauterine artificial insemination in sheep in a seasonaldependent manner: a 7-year study. International Journal of Biometeorology 59:585-592.
Salvador I, Viudes De Castro MP, Bernacer J, Gómez EA, Silvestre MA (2005) Factors affecting pregnancy rate in artificial insemination with frozen semen during non-breeding season in MurcianoGranadina goats: a field assay. Reproduction in Domestic Animals 40:526-529.

Zohary D, Tchernov E, Horwitz LK (1998) The role of unconscious selection in the domestication of sheep and goats. Journal of Zoology 245:129-135. 